\title{
Self-Assessment, Tax audit, Tax knowledge and Tax Compliance a Structural Equation Model (SEM) Approach
}

\author{
Abusomwan, Rachael Eloho (Mrs.) and OZIEGBE, David Jerry \\ Department of Accounting, Faculty of Social Sciences, Benson Idahosa University, Benin City, Nigeria
}

\begin{abstract}
The broad objective of this study is to examine the impact of tax assessment methods and compliance levels amongst small and medium scale enterprises in Edo state. The research design for this study is the exploratory research design. Primary data was used as the data source and well-structured likert scale questionnaire was developed for the research instrument. A total sample of 144 respondents was selected using the simple random sampling technique. The SEM is employed in this study to examine the causal relationships. The measurement model and then the full structural model were examined. Looking at the path analysis, it is observed that SAS do not have a direct impact on voluntary tax compliance However, SAS was then found to have an indirect impact on voluntary tax compliance through tax knowledge (TK) which is significant at $5 \%(p=0.000)$. This implies that the enactment of SAS in itself may not have a significant direct impact in improving tax compliance but can only be effective through improvement in other contextual factors such as tax knowledge. The direct effect of tax knowledge (TK) is positive significant at $5 \%$ but the direct effect of tax audit (TAU) on voluntary tax compliance is positive though not significant at $5 \%$. Hence the study recommends that the need for the tax authorities to improve enlightenment campaigns about self- assessment procedure to SME's. Secondly, tax authorities should work at improving tax knowledge through various mass media channels.
\end{abstract}

\section{INTRODUCTION}

$\mathrm{T}$ axes are unrequited in the sense that benefits provided by government to taxpayers are not normally in proportion to their payments. Taxes are, therefore, transfers of money to the public sector, but they exclude loan transactions and direct payments for publicly produced goods and services. Classifying tax by nominal source of taxation, we have by direct and indirect taxes. A direct tax is assessed and collected directly from the individuals who are intended to bear it while an indirect tax is not collected directly from the individuals who are intended to bear it. Tax compliance is a major problem for many tax authorities and it is not an easy task to persuade taxpayers to comply with tax requirements. The definition of tax compliance in its most simple form is usually cast in terms of the degree to which taxpayers comply with the tax law. However like many such concepts, the meaning of compliance can be seen almost as a continuum of definitions. This ranges from the narrow law enforcement approach, through wider economic definitions and on to even more comprehensive versions relating to taxpayer decisions to conform to the wider objectives of society as reflected in tax policy. Mohdali (2013) claimed that tax compliance should be defined as taxpayers' willingness to obey tax laws in order to obtain the economy equilibrium of a country. He argued that tax compliance can be thought out as the most neutral term to describe taxpayers' willingness to pay their taxes.

Consequently, tax compliance behaviour has been the subject of research in developed and developing nations (Assfawa, \& Sebhatb, 2019). In trying to address the menace of tax evasion and avoidance, different countries like Australia, the United States of America, the United Kingdom, Malaysia and Nigeria have introduced self-assessment over government assessment for voluntary compliance, as well as effective and efficient tax administration. Practice shows that voluntary compliance is best attained through a scheme of self-assessment. Self-assessment is targeted at shifting the duty of computing and filing tax returns to taxpayers. Under this scheme, the taxpayers accompany their tax returns with a self-assessment notice and an evidence of payment to the tax authority. Self-assessment scheme was introduced into the Nigerian tax laws was effectively implemented in 2011 through a project based scheme called self-assessment regime (Onyegbule, 2012). Section 24 (f) of the 1999 Constitution of the Federal Republic of Nigeria provides legal backing for the implementation of self-assessment, when it stated "that it shall be the duty of every citizen to declare his income honestly to appropriate and lawful agencies and pay his tax promptly. Thus, Self-assessment scheme is applicable to all taxable companies, person/agent for value added tax (VAT), self-employed and employees in Nigeria (Onyegbule, 2012). The focus of this study is to examine the effect of tax assessment regime/method on compliance levels amongst small and medium scale enterprises. The study also covers such areas as tax knowledge and tax audit on tax.

For years, compliance behaviour of tax payers has been the main challenge in many developing countries' tax system like Nigeria. According to CBN (2020) the ratio of tax revenue as a percentage of Gross Domestic Product (GDP) in Nigeria is eight percent (8\%). It is the second lowest in Africa and the fourth lowest in the world. It was the view of Emuwa (2016) that the Nigerian tax compliance behaviour is difficult. Moreover, based on the '2020 Ease of paying taxes' conducted by PricewaterhouseCoopers (PwC) and World 
Bank, Nigeria was at the position of 181 st of 189 th economies surveyed (PricewaterhouseCoopers, 2020). In order to stem this tide and reverse this trend of poor tax compliance levels, the self -assessment method (SAM) was introduced. As earlier stated, self-assessment scheme was introduced into the Nigerian tax laws and was effectively implemented in 2011 through a project based scheme called self-assessment regime (Onyegbule, 2012). However, most of the recent studies on tax compliance in Nigeria such as Gberegbe and Umoren (2017) Olaoye, Ayeni-Agbaje, Alaran-Ajewole (2017), Oladipupo and Obazee (2016) did not introduce the role of self-assessment system in affecting tax compliance. In addition, none of these studies have utilized the structural equations model approach in tax compliance study and these are gaps that this study addresses. Therefore, the objective of the study is to examine the impact of self-assessment alongside tax audit and tax knowledge on tax compliance in Nigeria.

\section{Research Objectives}

The specific objectives of this study are to:

- Examine the impact of self-assessment on tax compliance behaviour

- Examine the impact of tax audit on tax compliance behaviour in Nigeria under self-assessment scheme;

- Evaluate the impact of tax knowledge on tax compliance behaviour in Nigeria under selfassessment scheme.

Hypotheses of the Study

$\mathbf{H}_{\mathbf{0}}$ : Self-assessment has no significant impact on tax compliance behaviour

$\mathbf{H}_{\mathbf{0}}$ : Tax audit have no significant impact on tax compliance behaviour

$\mathbf{H}_{\mathbf{0}}$ : Tax knowledge has no significant impact on tax compliance behaviour.

\section{LITERATURE REVIEW}

\subsection{Voluntary Tax Compliance}

Voluntary tax compliance is a major problem for many tax authorities and it is not an easy task to persuade taxpayers to comply with tax requirements. The definition of tax compliance in its most simple form is usually cast in terms of the degree to which taxpayers comply with the tax law. However like many such concepts, the meaning of compliance can be seen almost as a continuum of definitions. This ranges from the narrow law enforcement approach, through wider economic definitions and on to even more comprehensive versions relating to taxpayer decisions to conform to the wider objectives of society as reflected in tax policy (Gberegbe \& Umoren 2017).

Andreoni, Erard and Feinstein (2008) claimed that tax compliance should be defined as taxpayers' willingness to obey tax laws in order to obtain the economy equilibrium of a country. Enofe, Embele \& Obazee (2019) perceived a simpler definition in which tax compliance is defined as the most neutral term to describe taxpayers' willingness to pay their taxes. A wider definition of voluntary tax compliance given by Song and Yarbrough (2008) suggested that tax compliance should be defined as taxpayers' voluntary ability and willingness to comply with tax laws which are determined by ethics, legal environment and other situational factors at a particular time and place. Similarly, tax compliance is also defined by several tax authorities as the ability and willingness of taxpayers to comply with tax laws, declare the correct income in each year and pays the right amount of taxes on time (Internal Revenue Service Act, 2000). Oladipupo and Obazee (2016) defined tax compliance as the reporting of all incomes and payment of all taxes by fulfilling the provisions of laws, regulations and court judgments. From the economic point of view, voluntary tax compliance has been defined as voluntary compliance with reporting requirements, meaning that the taxpayer files and pays all required tax returns at the proper time and that the returns accurately report tax liability in accordance with the taxing system applicable at the time the return is filed.

\subsection{Determinants of Voluntary Tax Compliance}

\subsubsection{Self-Assessment Scheme (SAS)}

The concept of Self-Assessment Regime describes a system of tax administration in which taxpayers are granted the right to objectively assess themselves to tax by computing their tax liabilities and paying such taxes on or before the due date as stipulated by law. Self-assessment scheme was introduced into the Nigerian tax laws was effectively implemented in 2011 through a project based scheme called self-assessment regime (Onyegbule, 2012). Section 24 (f) of the 1999 Constitution of the Federal Republic of Nigeria provides legal backing for the implementation of selfassessment.

Anyanduba and Oboh (2019) notes that a selfassessment regime encourages taxpayers to assess themselves and pay their tax liabilities voluntarily. The objectives of the SAR are to make payment of taxes easier for taxpayers, test the honesty and integrity of taxpayers, build trust in the taxpayers, increase revenue generation, minimise the cost of collection and tax disputes, and encourage voluntary compliance. The adoption of a SAS involves a substantial shift of responsibility to taxpayers in terms of computing accurate amounts of tax liabilities and making payments based on the computation. It also places the responsibility of maintaining and retaining proper records of business transactions upon the taxpayers to enable them to declare tax positions as accurately as possible. Thus compliance requirements of taxpayers are generally expected to increase under the SAS alongside reduction in compliance cost since most of the responsibilities of tax computation are more on tax payer (Anyanduba \& Oboh 2019; Okello, 2014). 


\subsubsection{Tax knowledge}

Knowledge as one of the factors in compliance is related to the taxpayers' ability to understand taxation laws, their willingness to comply and perhaps ways to reduce tax compliance costs. One aspect of knowledge that relates to compliance is the general understanding about taxation regulations and information pertaining to the opportunity to evade tax. According to Oladipupo and Obazee (2016) tax knowledge is the level of awareness or sensitivity of the taxpayers to tax legislation. Tax knowledge refers to the processes, by which taxpayers become aware of tax legislation and other tax-related information. Tax knowledge is necessary to increase public awareness especially in areas concerning taxation laws, the role of tax in national development (Mohd, 2010). Another aspect is knowledge of the compliance process itself. A clear knowledge of the compliance process will result in lower compliance costs since it will reduce confusion, mistakes, anxiety, frustration the likelihood to employ expensive tax professionals.

\subsubsection{Tax Audit}

Tax audit which is another component of economic factors, plays an important role in reporting compliance behaviour because taxpayers may state all incomes if they observe that they will be audited in that specific year (Richardson, 2008). Tax audit is a common and consistent feature in self-assessment scheme with the anticipation that all taxpayers will be audited at least once every five (5) years (Singh, 2005). Fiorio and Santoro (2012) investigate the response of taxpayers to an increase audit probability, using some evidence from Italy. They analyse a large data set produced by the tax agency for the study, made of about 50,000 firms. They found a positive relationship between taxpayers' response and probability of audit. Furthermore, increased probability of audit encourages tax compliance since it has direct deterrent influence on taxpayers audited and indirect deterrent influence on taxpayers not audited. Also, Modugu and Anyaduba (2014) investigate the impact of tax audit and other qualitative attributes on the tax compliance level of companies in Nigeria. They found a positive relationship between tax audit and tax compliance. More so, the probability of being audited and perception of government spending were found to also have significant effect on tax compliance in Nigeria.

\subsection{Empirical Review}

Olaoye, Ayeni-Agbaje, Alaran-Ajewole (2017) examined the impact of tax information, administration and knowledge on tax payers' compliance of Block Moulding Firms in Ekiti State, Nigeria using a survey research design. The data obtained from questionnaire were analysed using the ordinary least square regression method. The results showed that tax information and knowledge had positive significant impacts on tax compliance while tax administration had an insignificant impact on tax compliance. The study recommended that government should through its agencies educate the potential tax payers on tax laws and regulations by direct free symposia and seminars.

Oladipupo and Obazee (2016) investigated the impacts of tax payers' knowledge and penalties on tax compliance amongst small and medium enterprises in Nigeria using a survey research design. The data obtained from questionnaire were analyzed using the Ordinary Least Square regression method. The results showed that tax knowledge had a positive significant impact on tax compliance while tax penalty had insignificant positive impact on tax compliance. Thus, the study shows that tax knowledge has a higher tendency to promote tax compliance than tax penalty.

Olaoyea and Busari (2021) examined implications of tax audit and investigation on taxpayers 'compliance in Nigeria. The study employed cross-sectional survey research design, using a self-structured questionnaire administered to purposively selected senior members of Federal Inland Revenue Services (IFRS), a body responsible for tax collection and administration in Nigeria. Descriptive and inferential statistics were used. The descriptive result showed that regular tax audits influence tax compliance with $76.12 \%$ percentage of total Agree; the responses relatively vary as suggested by the computed standard deviation Inferential regressions analysis carried out which revealed that a tax audit and investigation had a positive statistical significant effect on tax compliance.

Hantono. (2021) examined the effect of tax knowledge, tax awareness and tax morale on tax compliance. The sampling was conducted by using an incidental sampling method. Methods of data collection through questionnaires that have been distributed to 100 respondents who have met the criteria. Multiple linear regression analysis shows that tax knowledge, tax awareness, and tax morale are significant toward tax compliance. The simultaneous have a significant effect on tax compliance. It can be concluded that tax knowledge mitigation, tax awareness, and tax morale towards tax compliance. The results of t-test showed that tax knowledge isn't approved and indicates it has a significant impact on affecting tax compliance, tax awareness has less impact on affecting tax compliance, tax morale was not significant.

Kojo, Martin, Ebenezer, Martin, Daniel Charlse (2020) examined the effect of dimensions of tax knowledge on tax compliance in the Ghanaian context using small and medium enterprises. The survey includes 130 managers of small business enterprises (SMEs) in Ghana, who had been part of a tax education campaign by the Ghana Revenue Authority in the Nkawkaw Municipality. The data was analysed using a structural equation modelling approach. The results of the study suggest that knowledge of tax rights and responsibilities, knowledge of employment income, and awareness of sanctions were found to have a positive and significant relationship with tax compliance. 
Anyanduba and Oboh (2019) examined the determinants of tax compliance behaviour under the selfassessment scheme in Nigeria. A non-random stratified sampling technique was used to evaluate taxpayer behaviour. Data was also gathered using questionnaire from three of the six geopolitical zones in Nigeria, namely South-South, SouthWest and North central zones respectively. The specific locations were Edo state, Lagos state, and Federal Capital Territory, Abuja resulting in 550 respondents which were analysed. The results showed that tax audit and awareness of offences and penalties had a positive and significant impact on tax compliance behaviour under the self-assessment scheme in Nigeria. Simplicity of tax administration and returns, tax knowledge and taxpayers' integrity had a positive but not significant impact on tax compliance behaviour under the selfassessment scheme in Nigeria.

\subsection{Theoretical Framework- Economic deterrence Theory}

Economic deterrence models in general are based on the theory that behaviour, in a wide range of contexts including tax evasion, is responsive to punishment or sanctions. Economic deterrence models tend to have a narrow, theoretical view of behaviour, reducing its dimensions to numerical measures and assigned probabilities from which outcomes can be predicted using calculus. In order to determine behaviour in this manner, economic deterrence models tend to rely upon a wide range of fundamental assumptions that are generally unrealistic. For example, that all people respond to a change in any one variable in an identical and predictable manner; that all taxpayers have a full knowledge of the probability of being audited; and that all taxpayers have the same level of risk preference. Although empirical testing has been limited, the theoretical principles of economic deterrence have been widely adopted by tax administrations in developing enforcement strategies that rely principally on penalties and the fear of getting caught (McKerchar \& Evans, 2009).

\section{METHODOLOGY}

The research design for this study is the exploratory research design. It is employed when the researcher is concerned with surveying responses from a sample of the population without any control on the elements of the sample and as such it is used extensively to collect information on numerous subjects of research. For this study, the population comprises of all small and medium scale enterprises operating in the manufacturing services Benin City Local Government Area of Edo State. The study adopts a sample of 144 of SME's. The sampling was done using the convenience sampling technique. The nature and non-availability of publicly available secondary data on SME's necessitated the use of primary data for the study. The data was generated using well-structured questionnaire. In filling the questionnaires the SMEs respondents will be guided during the survey. The study will make use of the Structural equations model (SEM) estimation technique using Stata 14.

\section{Model specification}

The model specification for the study adapts those of Olaoye, Ayeni-Agbaje, Alaran-Ajewole (2017) and Oladipupo and Obazee (2016) in investigating determinants of voluntary tax compliance amongst SME's. The model is specified below

$V T C=\partial_{0}+\partial_{1} S A S+\partial_{2} T K+\partial_{3} T A U+\mu_{i t}-\cdot-\cdot-\cdot--\cdot------($ iii $)$ Where $: S A S=$ Self-assessment Scheme, $V T C_{i}=$ Voluntary tax compliance, $T A U_{=}$Tax audit

$T K=$ tax knowledge and $\mu=$ error term

\section{PRESENTATION AND ANALYSIS OF RESULT}

Table 1. Analysis of Questionnaires

\begin{tabular}{|c|c|}
\hline $\begin{array}{c}\text { Total number of questionnaires } \\
\text { distributed }\end{array}$ & 455 \\
\hline Number of retrieved questionnaires & 400 \\
\hline $\begin{array}{c}\text { Number of questionnaires used for } \\
\text { analysis }\end{array}$ & 400 \\
\hline
\end{tabular}

Source: Field work, (2021)

Table 2. Demographic Evaluation of SMES

\begin{tabular}{|c|c|c|c|}
\hline \multicolumn{2}{|c|}{} & Frequency & Percent \\
\hline \multirow{3}{*}{ owner } & 186 & 46.5 \\
\cline { 2 - 4 } & employed manager & 170 & 42.5 \\
\cline { 2 - 4 } & someone else & 44 & 11.0 \\
\cline { 2 - 4 } & Total & 400 & 100.0 \\
\hline
\end{tabular}

Source: Field work, (2021)

The data revealed that 186 of the respondents indicated that the businesses were self-managed and that represented about $46.5 \%$ of the sample. 170 of the SMES sampled were managed by an employed manager and that represented about $42.5 \%$ of the sample. Finally, 44 of the 400 SME are sampled were managed by someone else such as a family member or relative. Hence, from the analysis, we concluded that most of the SMES sampled were managed by the owners.

Table 3. Source of finance

\begin{tabular}{|c|c|c|c|}
\hline \multicolumn{2}{|c|}{} & Frequency & Percent \\
\hline \multirow{3}{*}{ Valid } & personal savings & 120 & 30.0 \\
\cline { 2 - 4 } & friends/relatives & 186 & 46.5 \\
\cline { 2 - 4 } & financial institutions & 94 & 23.5 \\
& Total & 400 & 100.0 \\
\cline { 2 - 4 } & & & \\
\hline
\end{tabular}

Source: Field work, (2021)

In terms of their financing source, 120 of the SMES representing about $30.0 \%$ of the sample depended on personal savings to start their businesses although most of their respondents, about $46.5 \%$ of the sample, depended on friends/relatives. Only about $23.5 \%$ sourced their funding from financial institutions. 
Table 4: Sectorial Classification

\begin{tabular}{|c|c|c|c|}
\hline \multicolumn{1}{|c|}{} & Frequency & Percent \\
\hline \multirow{4}{*}{ Agriculture } & 37 & 9.3 \\
\cline { 2 - 4 } & business services & 57 & 14.3 \\
\cline { 2 - 4 } & $\begin{array}{c}\text { computer and related } \\
\text { services }\end{array}$ & 46 & 11.5 \\
\cline { 2 - 4 } & Construction & 40 & 10.0 \\
\cline { 2 - 4 } & hotels and restaurants & 49 & 12.3 \\
\cline { 2 - 4 } & Manufacturing & 92 & 23.0 \\
\cline { 2 - 3 } & wholesale and retail & 66 & 16.5 \\
\cline { 2 - 3 } & transport and storage & 13 & 3.3 \\
\cline { 2 - 3 } & Total & 400 & 100.0 \\
\hline
\end{tabular}

Source: Field work, (2021)

The table above showed that in terms of sectorial classification of the SMES, the data revealed that $37(9.3 \%)$ were in agriculture, 57(14.3\%) in business services, $40(10 \%)$ in construction and 66(3.3) are in wholesale and retail.

Table 5. Aggregate Descriptive Statistics for the variables Indicators

\begin{tabular}{|c|c|c|c|c|c|}
\hline & $\begin{array}{c}\text { MS } \\
\text { Mean } \\
\text { Score }\end{array}$ & $\begin{array}{c}\text { Standard } \\
\text { Error }\end{array}$ & $\begin{array}{c}\text { Standard } \\
\text { deviation }\end{array}$ & $\begin{array}{c}\text { Norma } \\
\text { lity } \\
\text { Test }\end{array}$ & $\begin{array}{c}\text { Cronb } \\
\text { ach } \\
\text { Alpha }\end{array}$ \\
\hline VTC & 2.373 & 0.02851 & 0.90149 & 87.925 & 0.87 \\
\hline SAS & 2.891 & 0.03076 & 0.97266 & 94.384 & 0.893 \\
\hline TK & 3.144 & 0.0307 & 0.97067 & 92.43 & 0.76 \\
\hline TAU & 3.085 & 0.03339 & 1.05588 & 87.925 & 0.81 \\
\hline
\end{tabular}

Source: Field work, (2021)
Table 5 shows the descriptive statistics for the variables and as observed the mean for VTC is 2.37 with a Cronbach-Alpha score for the construct is 0.87 . The mean for SAS is 2.891 with a Cronbach-Alpha score of 0.893 . The mean for TK is 3.144 with a Cronbach-Alpha score of 0.76 and the mean for TAU is 3.085 with a Cronbach-Alpha score of 0.81 . The Cronbach Apha's are all satisfactory and hence indicates the reliability of the research instrument.

Table 6. Kaiser's Measure of Sampling Adequacy (MSA

\begin{tabular}{|c|c|}
\hline & MSA \\
\hline VTC & 0.774551 \\
\hline SAS & 0.867927 \\
\hline TK & 0.683307 \\
\hline TAU & 0.779250 \\
\hline Kaiser's MSA & 0.733411 \\
\hline
\end{tabular}

Source: Field work, (2021)

This table shows two tests that indicate the suitability of your data for structure detection. The Kaiser-Meyer-Olkin Measure of Sampling Adequacy is a statistic that indicates the proportion of variance in your variables that might be caused by underlying factors. High values (close to 1.0) generally indicate that a factor analysis may be useful with your data. If the value is less than 0.50 , the results of the factor analysis probably won't be very useful. In this case the aggregate MSA is 0.733 which is satisfactory.

Table 8. Exploratory Factor Analysis for VTC

\begin{tabular}{|c|c|c|c|c|c|}
\hline & $\mathrm{F} 1$ & $\mathrm{~F} 2$ & Communality & Uniqueness & \\
\hline VTC-1 & -0.657407 & 0.097241 & 0.558365 & 0.441640 & \\
\hline VTC-2 & 0.031291 & 0.390136 & 0.846829 & 0.153185 & \\
\hline VTC-3 & -0.058645 & 0.281806 & 0.917147 & 0.082854 & \\
\hline VTC-4 & 0.013827 & 0.366457 & 0.865502 & 0.134482 & \\
\hline VTC-5 & 1.000000 & 0.000000 & 0.000000 & 1.000000 & \\
\hline Factor & Variance & Cumulative & Difference & Proportion & Cumulative \\
\hline $\mathrm{F} 1$ & 1.436793 & 1.436793 & 1.061426 & 0.792862 & 0.792862 \\
\hline $\mathrm{F} 2$ & 0.375367 & 1.812161 & & 0.207138 & 1.000000 \\
\hline Total & 1.812161 & 1.812161 & & 1.000000 & \\
\hline \multicolumn{6}{|c|}{ Exploratory Factor Analysis for TA } \\
\hline TA-1 & -0.176061 & -0.142204 & 0.948816 & 0.051220 & \\
\hline TA-2 & 0.527769 & 0.550935 & 0.417934 & 0.582070 & \\
\hline TA-3 & 0.115408 & -0.182974 & 0.953230 & 0.046798 & \\
\hline TA-4 & 1.000000 & $-2.18 \mathrm{E}-17$ & 0.000000 & 1.000000 & \\
\hline TA-5 & -0.092403 & 0.097752 & 0.981907 & 0.018094 & \\
\hline
\end{tabular}




\begin{tabular}{|c|c|c|c|c|c|}
\hline Factor & Variance & Cumulative & Difference & Proportion & Cumulative \\
\hline $\mathrm{F} 1$ & 1.331395 & 1.331395 & 0.964610 & 0.784013 & 0.784013 \\
\hline $\mathrm{F} 2$ & 0.366786 & 1.698181 & & 0.215987 & 1.000000 \\
\hline Total & 1.698181 & 1.698181 & & 1.000000 & \\
\hline \multicolumn{6}{|c|}{ Exploratory Factor Analysis for SAS } \\
\hline SAS-1 & -0.287837 & -0.137813 & 0.898157 & 0.101843 & \\
\hline SAS-2 & 0.290599 & 0.099689 & 0.905614 & 0.094386 & \\
\hline SAS-3 & -0.108074 & 0.269159 & 0.915874 & 0.084126 & \\
\hline SAS-4 & 0.179002 & -0.220937 & 0.919145 & 0.080855 & \\
\hline Factor & Variance & Cumulative & Difference & Proportion & Cumulative \\
\hline $\mathrm{F} 1$ & 0.211020 & 0.211020 & 0.060830 & 0.584203 & 0.584203 \\
\hline $\mathrm{F} 2$ & 0.150190 & 0.361210 & & 0.415797 & 1.000000 \\
\hline Total & 0.361210 & 0.361210 & & 1.000000 & \\
\hline \multicolumn{6}{|c|}{ Exploratory Factor Analysis for TAU } \\
\hline TAU-1 & 0.075014 & 0.127415 & 0.978139 & 0.021862 & \\
\hline TAU-2 & $6.52 \mathrm{E}-15$ & 1.000000 & 0.000000 & 1.000000 & \\
\hline TAU-3 & -0.011901 & -0.087074 & 0.992277 & 0.007723 & \\
\hline TAU-4 & 0.960556 & 0.083081 & 0.070430 & 0.929570 & \\
\hline TAU-5 & 0.548838 & 0.029912 & 0.697914 & 0.302117 & \\
\hline Factor & Variance & Cumulative & Difference & Proportion & Cumulative \\
\hline $\mathrm{F} 1$ & 1.229659 & 1.229659 & 0.198046 & 0.543791 & 0.543791 \\
\hline $\mathrm{F} 2$ & 1.031614 & 2.261273 & & 0.456209 & 1.000000 \\
\hline Total & 2.261273 & 2.261273 & & 1.000000 & \\
\hline
\end{tabular}

Table 8 shows the exploratory factor analysis is conducted for sub-variables of each of the constructs and as observed for a 2 -factor model is identified for the VTC, TA, SAS and TAU. The loadings of the sub variables as indicated by the Eigen values are also shown in the results. Importantly, the uniqueness of the sub variables is key to their inclusion in the SEM. Normally, the greater 'uniqueness' the lower the relevance of the variable in the factor model and hence indicating that the sub-variables are all correlated and hence tend to measure the same construct. From the survey of the uniqueness of the sub-variables, it can be observed that the uniqueness estimates are all quite low and hence their usefulness in the factor model and the SEM model subsequently.
Table 9: CFA for Self-Assessment Measurement Model

Fit statistic | Value Description

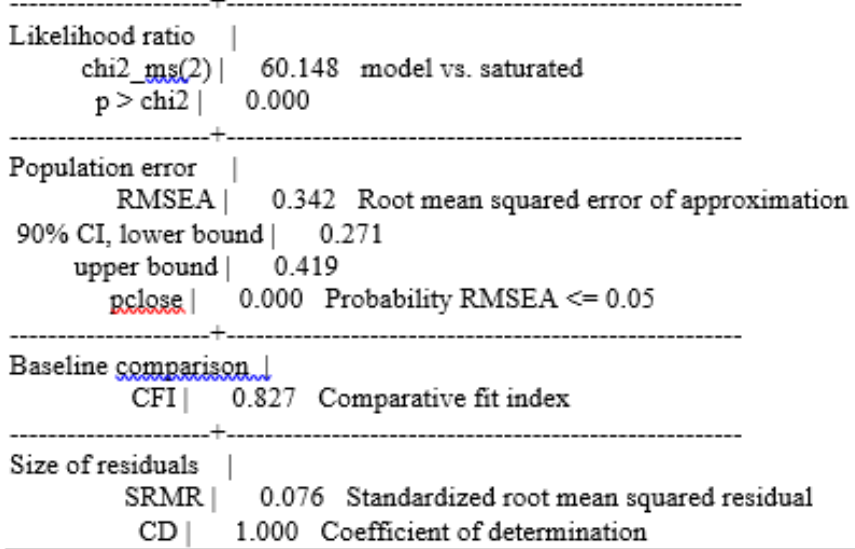

RMSEA | 0.342 Root mean squared error of approximation

Source; STATA 13 
The fit statistics for the measurement model for SAS measurement model is presented in table 9 above and as observed earlier, the ensuring a good fit for the measurement model is a core basic framework for their subsequent usage in the full structural model. SAS has for basic factor measurement. Namely, SAS-1, SAS-2, SAS-3 and SAS-4. The contents of each is seen in the questionnaire (appendix 1). The fit statistics for the 4-factor SAS measurement model shows the chi-square value of 60.148 which is significant at the 0.05 level. The p-value is 0.00 suggesting that the model fitted the data acceptably in our population. Other fit indices included the comparative fit index $(\mathrm{CFI})=0.827$, and RMSEA $=0.342$ with $p$-value of 0.000 which indicates statistical significance. The Standardized root mean squared residual at 0.076 is low and all these statistics confirm the measurement fit of the SAS-4 factor model.

Table 10: CFA for Tax Audit (TA) Measurement Model

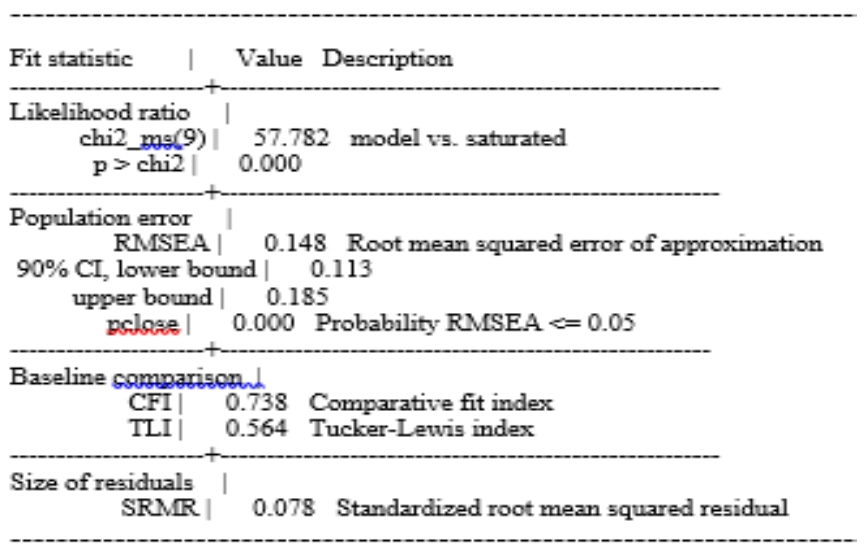

Source; STATA 13

The fit statistics for the measurement model for TA model is presented in table 2 . The fit statistcs for the 5-factor TA model reveals that the chi-square value of 57.78 is statistically significant at $5 \%$ which again indicates that the model fitted the data acceptably well. The CFI is 0.735 which is satisfactory as it maintains closeness to 1, the RMSEA of 0.145 with $p$-values of 0.000 is statistically significant and confirms the model fit. The Standardized root mean squared residual at 0.078 is low and all these statistics confirm the measurement fit of the 6 factor model.

Table 3: CFA for Tax Knowledge Measurement model

\begin{tabular}{|c|}
\hline Fit statistic I Value Description \\
\hline 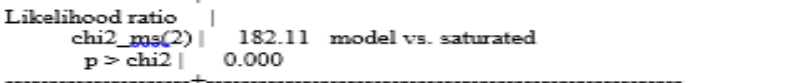 \\
\hline 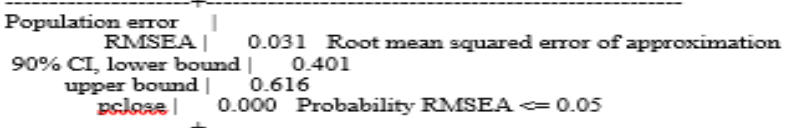 \\
\hline $\begin{array}{l}\text { Baseline comparisonul } \\
\text { CFI } \mid\end{array} 0.894$ Comparative fit index \\
\hline $\begin{array}{c}\text { Size of residuals } \\
\text { SRMR | } 0.052 \text { Standardized root mean squared residual } \\
\text { CD | } 1.000 \text { Coefficient of determination }\end{array}$ \\
\hline
\end{tabular}

Source; STATA 13
The fit statistics for the measurement model for Tax Knowledge measurement Model is presented in table 10. The fit statistics for the 6-factor model reveals that the chi-square value of 182.11 is statistically significant at $5 \%$ which again indicates that the model fitted the data acceptably well. The CFI is 0.894 which is satisfactory as it maintains closeness to 1 , the RMSEA of 0.145 with p-values of 0.000 is statistically significant and confirms the model fit. The Standardized root mean squared residual at 0.078 is low and all these statistics confirm the measurement fit of the 5 factor model.

Table 12: CFA for Voluntary Tax Compliance Measurement model

\begin{tabular}{|c|c|}
\hline Fit statistic $\quad \mid$ & Value Description \\
\hline $\begin{array}{l}\text { Likelihood ratio } \\
\text { chi2_mo(2) } \\
\text { p }>\text { chi2 } \mid\end{array}$ & $\begin{array}{l}102.50 \text { model vs. saturated } \\
0.000\end{array}$ \\
\hline $\begin{array}{l}\text { Population error } \\
\text { RMSEA | } \\
90 \% \text { CI, lower bou } \\
\text { upper bound | } \\
\text { pcloge | }\end{array}$ & $\begin{array}{l}0.004 \text { Root mean squared error of approximation } \\
\text { and } 0.401 \\
0.616 \\
0.000 \text { Probability RMSEA }<=0.05\end{array}$ \\
\hline $\begin{array}{l}\text { Baseline compariso } \\
\text { CFI | }\end{array}$ & $\begin{array}{l}\text { Ind } \\
0.994 \text { Comparative fit index }\end{array}$ \\
\hline $\begin{array}{r}\text { Size of residuals | } \\
\text { SRMR | } \\
\text { CD } \mid\end{array}$ & $\begin{array}{l}0.005 \text { Standardized root mean squared residual } \\
1.000 \text { Coefficient of determination }\end{array}$ \\
\hline
\end{tabular}

Source; STATA 13

The fit statistics for the measurement model for the Voluntary Tax Compliance measurement Model is presented in table 4. The fit statistics for the 5-factor voluntary tax compliance model reveals that the chi-square value of 102.50 is statistically significant at $5 \%$ which again indicates that the model fitted the data acceptably well. The CFI is 0.994 which is satisfactory as it maintains closeness to 1, the RMSEA of 0.004 with p-values of 0.000 is statistically significant and confirms the model fit. The Standardized root mean squared residual at 0.005 is low and all these statistics confirm the measurement fit for the Voluntary Tax Compliance model.

\subsection{Structural Equation Modelling (SEM)}

The SEM is employed in this study to examine the causal relationships. Averaging the scores for a scale was the method used to create a single value for each of the observed variables in the managerial performance model. The measurement model and then the full structural model were tested using each data set. Maximum likelihood (ML) estimation method is sufficiently robust to perform well even when data are non-normal and the model is misspecified. Therefore, the robust maximum likelihood (RML) method was used to estimate parameters for this model and fit indices. 
Figure 1: Structural Equation Model for Determinants of VTC

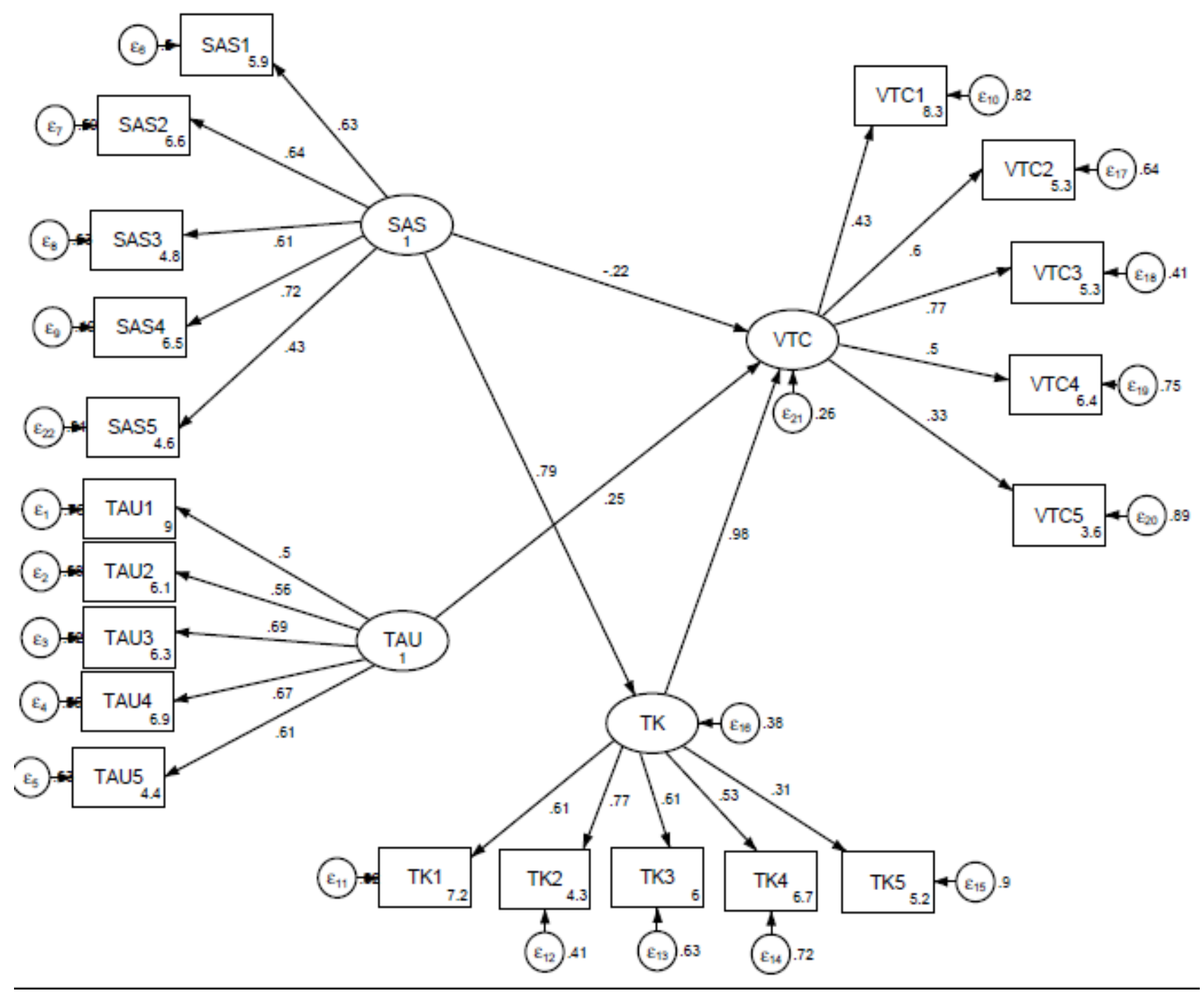

\begin{tabular}{|c|c|c|c|}
\hline Path Analysis & Coefficient & Standard Error & P-value \\
\hline \multicolumn{4}{|c|}{ Direct Effects } \\
\hline $\mathrm{SAS} \longrightarrow \mathrm{VTC}$ & -0.2194 & 0.3893 & 0.573 \\
\hline $\mathrm{TK} \longrightarrow \mathrm{VTC}$ & 0.9544 & 0.3325 & 0.003 \\
\hline $\mathrm{TAU} \longrightarrow \mathrm{VTC}$ & 0.2545 & 0.2001 & 0.203 \\
\hline $\mathrm{SAS} \longrightarrow \mathrm{KK}$ & 0.7873 & 0.0865 & 0.000 \\
\hline \multicolumn{4}{|c|}{ Indirect effects } \\
\hline $\mathrm{SAS} \longrightarrow \mathrm{VTC}$ & 0.3855 & 0.18710 & 0.039 \\
\hline \multicolumn{3}{|c|}{ Fit statistics } & \\
\hline & $\begin{array}{r}\text { Comparat } \\
\text { SN } \\
\text { Chi squa } \\
\end{array}$ & $\begin{array}{l}=0.872 . \\
(0.000)\end{array}$ & \\
\hline
\end{tabular}


The regression result from path analysis of SEM of the model specified earlier in the previous chapter. The structural model has an overall $\mathrm{R}^{2}$ is 0.872 which implies that the structural equations model explains about $87,2 \%$ of the systematic variations in the dependent variable. The full structural model was then tested and again to assess the fitness. The two most common ways of evaluating model fit are use of the chi-square goodness-of-fit statistic and the use of other absolute or relative fit indices such as the CFI, RMSEA amongst others. The chi-square goodness-of-fit statistic assesses the magnitude of the difference between the sample and fitted covariance matrices. It indicate a reasonable model fit with a value of 997.5242 .33 which is statistically significant at $5 \%$. This is further supported by the RMSEA which is 0.054 and CFI which stood at 0.872 . The fit indices confirm the primary hypothesis that the overall voluntary compliance model is valid. Looking at the path analysis, it is observed that SAS do not have a direct impact on voluntary tax compliance as indicated by the beta $(-0.2194)$ which is not significant $(\mathrm{p}=0.573)$ at $5 \%$. However, SAS was then found to have an indirect impact on voluntary tax compliance through tax knowledge (TK) as indicated by the indirect effect beta 0.3866 which is significant at $5 \%(\mathrm{p}=0.000)$.

This implies that the enactment of SAS in itself may not have a significant direct impact in improving tax compliance but can only be effective through improvement in other contextual factors such as tax knowledge. It appears therefore, that the effect of SAS on voluntary tax compliance can be significant if there is improvement in tax knowledge. A proper understanding of the relevant tax laws and the procedures for self-assessment by taxpayers are a necessary condition for an effective implementation of a SAR. If SME's have little or no knowledge about their tax responsibility and the processes but in place by tax authorities to simplify tax complexities, then the impact of SAS regime will not be felt and thus the tax knowledge mediates the relationship between SAS and VTC (Okello, 2014). The direct effect of tax knowledge (TK) is positive (0.9544) significant at 5\% $(p=003)$. The level of formal general education received by taxpayers is an important factor that contributes to the understanding of tax requirements, especially regarding registration and filling requirements. Another aspect is knowledge of the compliance process itself. A clear knowledge of the compliance process will result in lower compliance costs since it will reduce confusion, mistakes, anxiety, frustration the likelihood to employ expensive tax professionals. The study findings are in tandem with Oladipupo and Obazee (2016), Mohd, (2010) and Mohani, (2003) and Olaoye, Ayeni-Agbaje, Alaran-Ajewole (2017). The direct effect of tax audit (TAU) is positive (0.2545) though not significant at 5\% $(\mathrm{p}=203)$. In relation to the positive sign of the variable, the finding is in tandem with Fiorio and Santoro (2012) and Modugu and Anyaduba (2014).

\section{CONCLUSION AND RECOMMENDATION}

Taxation remains an important area of concern and an integral component of public policy. In Nigeria, like in most developing countries, tax compliance is posing a critical challenge to tax administration and affecting the fiscal system vis-a -vis revenue performance. Looking at the path analysis, it is observed that SAS do not have a direct impact on voluntary tax compliance However, SAS was then found to have an indirect impact on voluntary tax compliance through tax knowledge (TK) which is significant at 5\% ( $\mathrm{p}=0.000)$. This implies that the enactment of SAS in itself may not have a significant direct impact in improving tax compliance but can only be effective through improvement in other contextual factors such as tax knowledge. If SME's have little or no knowledge about their tax responsibility and the processes but in place by tax authorities to simplify tax complexities, then the impact of SAS regime will not be felt and thus the tax knowledge mediates the relationship between SAS and VTC The direct effect of tax knowledge (TK) is positive significant at $5 \%$ and thus the level of formal general education received by taxpayers is an important factor that contributes to the understanding of tax requirements, especially regarding registration and filling requirements but the direct effect of tax audit (TAU) on voluntary tax compliance is positive though not significant at 5\%. Hence the study recommends that the need for the tax authorities to improve enlightenment campaigns about self- assessment procedure to SME's. Secondly, tax authorities should work at improving tax knowledge through various mass media channels. It is also important for compliance complexity to be addressed as much as possible. In addition there is need for private sector tax information sharing/knowledge. This study is not without a few limitations and importantly in this regard is the examination of a limited number of possible tax compliance determinants in the midst of a rising number of factors.

\section{REFERENCES}

[1] Alabede,J Zaimah A Ariffin Z \& Kamil, L. (2011). Individual taxpayers' attitude and compliance behaviour in Nigeria: The moderating role of financial condition and risk preference Journal of Accounting and Taxation 3(5), Pp. 91-104,

[2] Anyaduba, J \& Oboh, T. (2019).Determinants of tax compliance behaviour under the self-assessment scheme in Nigeria. Accounting and Finance Research 8(2), Pp. 12-34

[3] Assfawa, A. M., \& Sebhatb, W. (2019). Analysis of tax compliance and its determinants: Evidence from Kaffa, Bench Maji and Skeka zones Category B Ta payers, SNNPR, Ethiopia. Journal of Accounting, Finance and Auditing Studies, 5(1), Pp. 32-58.

[4] Emuwa, T. I. (2016). Tax legislation for SME's. Taxation Roundtable Chamber of Commerce \& Industry, Lagos.

[5] Enofe, A., Embele, K., \& Obazee, E. P. (2019). Tax audit, investigation, and tax evasion. Journal of Accounting and Financial Management, 5(4), Pp. 47-66.

[6] Fajar O.P (2012). The influence of tax fairness and communication on voluntary compliance: Trust as an Intervening Variable. International Journal of Business and Social Science 3(21) Pp. 191-100.

[7] Fiorio, C., \& Santoro, A. (2012). Taxpayer response to an increased probability of audit: Some evidence from Italy. Retrieved from https://www.ssrn.com 
[8] Gberegbe, B., \& Umoren, A (2017). The perception of tax fairness and personal income tax compliance of Smes in Rivers State. Journal of Research in Business and Management 5(2), Pp. 40-51

[9] Hantono. (2021). the impact tax knowledge, tax awareness, tax morale toward tax compliance International Journal of Research, 9(1), Pp. 49-65.

[10] Ibrahim, M. (2010). African governance summary. Mo Ibrahim Foundation. Retrieved March 17, 2017 from www.moibrahimfoundation.org.

[11] Kojo, K., Martin, K., Ebenezer, N., Martin, A., Daniel, E., \& Charlse, K. (2020). Tax knowledge and tax compliance of small and medium enterprises in Ghana. South East Asia Journal of Contemporary Business, Economics and Law, 21(5),1 Pp. 2-34

[12] Maseko. N (2012). Determinants of tax compliance in small and medium: enterprises in Zimbabwe technical services. Retrieved from www.ssrn.com.

[13] McBannet, H. (2001). Tax compliance of companies in Croatia. Retrieved from http://www.iweb.cerge-ei.cz/pdf/gdn/RRCII 11 paper_05.pdf

[14] Mekerchar M, \& Evans .J.(2009). Tax evasion, civic duty and the law abiding citizen. Europe Journal of Political Econs. 19(1): Pp. 83-102.

[15] Merima, A, Fjeldstad, O \& Sjursen H. (2014), Factors affecting tax compliant attitude in Africa: Evidence from Kenya, Tanzania, Uganda and South Africa. Retreived from www.ssrn.com on November $20^{\text {th }} 2014$.

[16] Modugu, K. P., \& Anyaduba, J. O. (2014). Impact of tax audit on tax compliance in Nigeria. International Journal of Business and Social Science, 5(9), Pp. 207-215.

[17] Mohd J.A, (2010). Taxpayer compliance: An agenda for research, volume 2. Philadelphia: University of Pennsylvania Press.
[18] Mohdali R. (2013). The effects of religiosity and taxpayers' perceptions towards government on voluntary tax compliance. Tax Policy Research Unit (TPRU), School of Economics and Finance, Curtin University, Western Australia.

[19] Okello, A. (2014). Managing income tax compliance through selfassessment. International Monetary Fund Working Paper, 1-37.

[20] Oladipupo, A.O. \& Obazee, U. (2016). Tax knowledge, penalties and tax compliance in small and medium scale enterprises in Nigeria. iBusiness, 8(2), Pp. 1-9.

[21] Olaoye, O., Ayeni-Agbaje, C., Alaran-Ajewole, T (2017) Tax information, administration and knowledge on tax payers' compliance of block moulding firms in Ekiti State. Journal of Finance and Accounting 5(4), Pp. 131-138

[22] Olaoyea, S \& Busarib, T. (2021). Implications of tax audit and investigation on taxpayers' compliance in Nigeria. International Journal of Innovation, Creativity and Change. 15(3) Pp.4-21

[23] Onyegbule, N. C., (2012). Self-assessment practice in Nigeria.. Retrieved from http://www.vanguardngr.com/2012/06/selfassessment-practice-in-Nigeria

[24] Palil, M. R. (2010). Tax knowledge and tax compliance determinants in self assessment system in Malaysia.Retrieved from http://etheses.bham.ac.uk/1040/1/Palil10PhD.pdf on 5th April, 2017.

[25] PwC (2016). Paying taxes. World Bank Group. Retrieved from www.ssrn.com.

[26] Richardson G (2006). Determinants of tax evasion: A cross country investigation. J. Int. Acc. Auditing Taxation, 15(2), Pp. 150-169.

[27] Singh, S. P. (2003). Legal and administrative sources of tax compliance costs in India, New delhi: national institute of public finance and policy, mimeo. 